\title{
COMPARATIVE STUDY OF SINGLE-PHASE PWM RECTIFIER CONTROL TECHNIQUES
}

\author{
Evren ISEN*, Electrical Engineering, Bandirma Onyedi Eylul University, Turkey, eisen@bandirma.edu.tr
} (iD https://orcid.org/0000-0002-3107-9255)

Received: 30.01.2021, Accepted: 04.03.2021

*Corresponding author

Research Article

DOI: $10.22531 /$ muglajsci.870989

\begin{abstract}
In this study, $2.5 \mathrm{~kW}$ single-phase pulse-width modulated rectifier is simulated with three different control techniques to investigate the performance of controllers. Rectifier simulation is performed in Matlab / Simulink environment by using hysteresis current control, sinusoidal pulse width modulation and voltage oriented control techniques. In the performance comparison of the control techniques, considering the switching frequencies, the total harmonic content of the current drawn from the grid, the phase difference between the grid voltage and the grid current, and the DC bus voltage regulation at the output are considered as comparison criteria. The switching frequency is set to $35 \mathrm{kHz}$ in sinusoidal pulse width modulation and voltage oriented control techniques. Since the switching frequency is variable in the hysteresis current control technique, the average and instantaneous switching frequency are calculated for different hysteresis band values. In the results with the technique, the switching frequency varies between $18.52 \mathrm{kHz}$ and $47.6 \mathrm{kHz}$, while the average switching frequency is $34.6 \mathrm{kHz}$. As a result, the total harmonic distortion of the grid current with hysteresis current control, sinusoidal pulse width modulation and voltage oriented control techniques is 3.69\%, 1.12\% and $1.82 \%$, respectively. The synchronization with the grid voltage is achieved with all techniques, and the DC voltage is regulated with active power.
\end{abstract}

Keywords: Hysteresis current control, Sinusoidal PWM, Rectifier

\section{TEK FAZLI PWM DOĞRULTUCU KONTROL TEKNIKKLERINIIN KARŞILAŞTIRILMASI}

\section{Özet}

Bu çalıșmada, $2.5 \mathrm{~kW}$ gücünde tek fazlı darbe genişlik modülasyonlu doğrultucunun üç farklı kontrol yönteminde simülasyonu yapılarak bu yöntemlerin performansı incelenmiştir. Histerezis akım kontrolü, sinüzoidal darbe genişlik modülasyonu ve gerilim odaklı kontrol yöntemleri kullanılarak Matlab/Simulink ortamında doğrultucu simülasyonu gerçekleştirilmiştir. Kontrol yöntemlerinin performans karşılaştırmalarında anahtarlama frekansları dikkate alınarak şebekeden çekilen akımın toplam harmonik içeriği, şebeke gerilimi ile arasındaki faz farkı ve çıkıştaki DC bara gerilimi regülasyonu karşılaştırma kriterleri olarak ele alınmıştır. Sinüzoidal darbe genişlik modülasyonu ve gerilim odaklı kontrol yöntemlerinde anahtarlama frekansı $35 \mathrm{kHz}$ seçilmiştir. Histerezis kontrol yönteminde anahtarlama frekansı değişken olduğundan dolayı farklı hata bandı değerleri için anahtarlama frekans değişimi hesaplanarak ortalama ve anlık anahtarlama frekansı tespit edilmiştir. Histerezis akım kontrol yönteminde anahtarlama frekansı 18,52 kHz ile 47,6 $\mathrm{kHz}$ aralığında değișirken ortalama anahtarlama frekansı 34,6 kHz olmuștur. Yapılan çalışma sonucunda histerezis akım kontrolü, sinüzoidal darbe genişlik modülasyonu ve gerilim odaklı kontrol yöntemlerinde şebeke akımı toplam harmonik bozulumu sirasıla \%3,69, \%1,12 ve \%1,82 olmuştur. Tüm yöntemlerde şebeke ile senkronizasyon sağlanmış ve DC bara gerilimi regülasyonu şebekeden aktif güç çekerek gerçekleştirilmiştir.

Anahtar Kelimeler: Histerezis akım control, Sinüzoidal PWM, Doğrultucu

Cite

ISEN, E., (2021). “Comparative Study Of Single-Phase Pwm Rectifier Control Techniques”, Mugla Journal of Science and Technology, 7(1), 44-51.

\section{Introduction}

Rectifier circuits are used in many industrial applications such as uninterruptible power supplies [1], wind turbines [2], electric vehicle charging systems [3], DC motor control [4], active filter [5], electric locomotive [6] and STATCOM [7] applications. Depending on the usage power, single-phase rectifiers are used at low power, and three-phase rectifiers are used at high power applications [8]. Three-phase rectifiers have some advantages such as higher output 
voltage, lower ripple, higher overall efficiency and simple filtering [9]. Rectifiers using diodes are called uncontrolled rectifiers, while rectifiers that use controlled semiconductors such as MOSFET, IGBT, thyristor are also called controlled rectifiers. Since MOSFET and IGBT are forced commutated elements, pulse width modulation (PWM) can be applied, and current in the desired waveform can be drawn from the AC side of the rectifier. Thus, low harmonic current and high power factor are obtained. Thyristor is used as a switching element in very high power applications. However, because the thyristor is self-commutated, pulse width modulation cannot be used, and the current harmonic content is higher [10].

$\mathrm{L}$, LC or LCL filter is used for filtering the current drawn from the AC source in rectifier circuits [11]-[13]. While L filter provides advantage in terms of design simplicity, it is weaker in terms of harmonic attenuation compared to LC and LCL filters. LC filter is used to reduce the grid voltage and current ripple. It has more filtering capability than $\mathrm{L}$ filter. There is a resonance risk between filter capacitor and grid inductor depending on the connection point. Another drawback of the filter is inrush current [14]. Although the LCL filter has a more effective filtering feature, it has some difficulties at the point of design. Resonance is suppressed by taking this situation into consideration in the design of the controller or by using the resistance in the filter, since there may be resonance in the filter consisting of inductance and capacitor elements. However, in this case, additional power loss occurs on the resistance. In order to prevent this power loss, different methods are used in the control algorithm and the algorithms become complex [15].

In controlled rectifiers, the current drawn from the $\mathrm{AC}$ source should be synchronized with the grid, in other words, the grid synchronization should be done with high power factor. Therefore, the grid angle must be determined. The Phase-locked Loop (PLL) method is a popular method used in grid angle detection [16].

In this study, the simulation of a PWM controlled singlephase grid-connected rectifier is carried out in Matlab/Simulink environment to investigate the controller performances. Using the hysteresis current control (HCC), sinusoidal PWM (SPWM) and voltage oriented control (VOC) to rectifier, the performance of the control techniques on the rectifier has been presented comparatively. Performances of control techniques are compared in terms of total harmonic content, switching frequency, grid synchronization and DC voltage regulation. Since switching frequency is different in HCC control technique, average switching frequency value is calculated, and compared with other control techniques.

\section{System Description}

The simulated system in the study is seen in Figure 1. The rectifier consists of four IGBT switches connected to the single-phase grid via inductor. The inductor is used to filter the grid current. In order to provide bidirectional current flow, parallel connected reverse diodes are used in the IGBTs. Electrolytic DC capacitor is used for voltage filtering at the output of the rectifier to provide constant voltage. A load is used at the output to model the power drawn from the rectifier. Depending on the application, the output can be a DC motor, DC/DC converter or an inverter. Since the focus of the study is rectifier control, a load block in Simulink is used at the output.

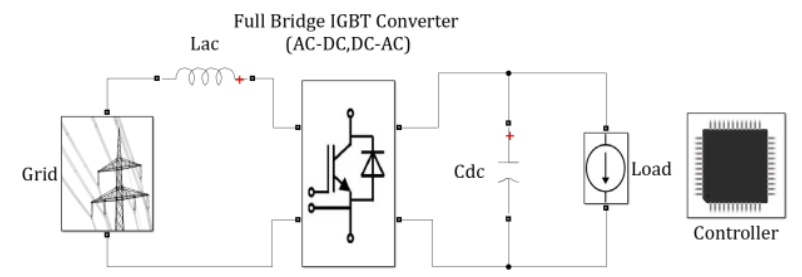

Figure 1. The simulated system.

The equations of the mathematical model of the rectifier are given in (1)-(4). By using Kirchoff Voltage Law theorem, equation (1) can be written. In the equation, $S$ is a switching function. It changes with states of upper switches as -1 and 1 . DC side of the rectifier can be modeled with equations (2)-(4). In the equations, $v_{g}$ and $v_{d c}$ are grid and DC output voltage, respectively. $i_{d c}$ is DC output current of converter. $i_{c}$ and $i_{\text {Load }}$ define capacitor and load currents. $R_{L}$ is an inductor resistance, and $i_{g}$ is grid current. Converter output current can be defined with $S$ function [17].

$$
\begin{gathered}
v_{g}=L_{a c} \frac{d i_{g}}{d t}+R_{L} i_{g}+S v_{d c} \\
i_{d c}=i_{c}+i_{\text {Load }} \\
i_{d c}=S i_{g} \\
i_{c}=C_{d c} \frac{d v_{c}}{d t}
\end{gathered}
$$

\section{Control of Single-Phase PWM Rectifier}

In controlled converters connected to the grid, the angle between the grid current and the grid voltage should be controlled. Thus, the power factor can be adjusted, and reactive power control can be made when it is required. After the grid angle is determined, the grid current is produced by the control algorithm depending on the reference current value, and switching signals are produced with the preferred modulation technique. In this study, rectifier control is performed by using hysteresis current control technique, sinusoidal PWM technique and voltage oriented control technique. In the controlled rectifier control, it is aimed to ensure that the currents drawn from the grid are sinusoidal and synchronized with the grid voltage, and the DC bus voltage regulation is ensured. For this reason, in each technique, the grid current value that provides DC bus voltage regulation is calculated first. Then, with the techniques described below, currents at this reference value are drawn from the grid. As seen in Figure 2, the 
grid voltage, the grid current and the DC bus voltage is measured to ensure synchronization, control, and regulation, respectively. The same circuit and measurements are used in all three techniques in the study. The parameters used in the all control techniques are given in Table 1. Switching frequency value is not fixed for HCC because it has variable frequency. Hysteresis band value is only used in HCC.

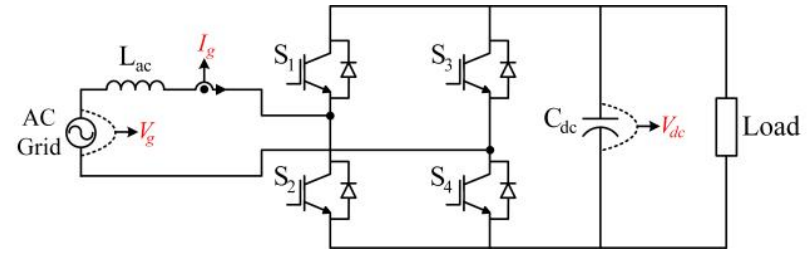

Figure 2. Single-phase PWM rectifier circuit.

Table 1. Circuit parameters

\begin{tabular}{cc}
\hline Parameter & Value \\
\hline Grid voltage $\left(V_{g}\right)$ & $220 \mathrm{~V}$ \\
Rectifier Power $\left(P_{0}\right)$ & $2.5 \mathrm{~kW}$ \\
Filter inductance $\left(L_{a c}\right)$ & $3 \mathrm{mH}$ \\
DC capacitor $\left(C_{d c}\right)$ & $4700 \mu \mathrm{F}$ \\
Switching frequency $\left(f_{s w}\right)$ & $35 \mathrm{kHz}$ \\
Hysteresis Band $(\Delta i)$ & $0.6 \mathrm{~A}$ \\
\hline
\end{tabular}

The used PLL method for grid angle determination is Synchronous Reference Frame PLL (SRF-PLL) in this study. SRF-PLL block diagram is seen in Figure 3.

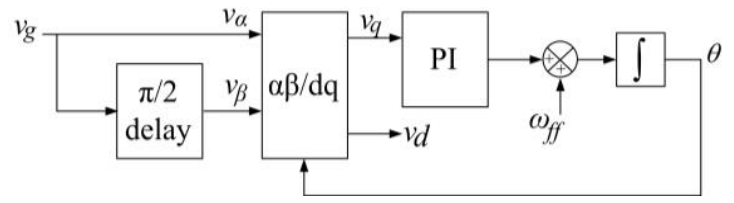

Figure 3. SRF-PLL block diagram.

This method is applied in Stationary Reference Frame that has $\alpha$ and $\beta$ components and Synchronous Reference Frame that has $d$ and $q$ components. In this method, $q$ component of the grid voltage is passed through low pass filter, and the output is added to fundamental frequency. Integrating the sum of frequencies gives the grid angle. It is used for $\alpha-\beta$ $/ d-q$ transformation. In three phase systems, $\alpha-\beta$ components are obtained from $a-b-c$ components. However, the $\beta$ component of a signal is provided by delaying the signal by $\pi / 2$ in single-phase systems. $\beta$ component is produced with $90^{\circ}$ phase difference with $\alpha$ component. $A-\beta$ component are transformed into $d-q$ frame by (5). The PI parameters used in the simulation in the PLL algorithm are $\mathrm{k}_{\mathrm{p}}=2$ and $\mathrm{k}_{\mathrm{i}}=1$.

$$
\left[\begin{array}{l}
v_{d} \\
v_{q}
\end{array}\right]=\left[\begin{array}{cc}
\cos \omega t & \sin \omega t \\
-\sin \omega t & \cos \omega t
\end{array}\right]\left[\begin{array}{c}
v_{\alpha} \\
v_{\beta}
\end{array}\right]
$$

The calculated grid angle variation is given in Figure 4. As seen in the figure, the calculated angle is synchronized with grid voltage. It is the main issue in grid connected converters.



Figure 4. Grid angle and grid voltage.

\subsection{Hysteresis Current Control}

The hysteresis current control is a control technique that controls current directly, and is preferred in terms of application simplicity and fast dynamic response [18]. In this control technique, the error between the reference current generated in the control algorithm, and the actual current is calculated. The relevant semiconductors in the converter are switched so that the current flows within the lower and upper limits determined for the error value. Figure 5 shows current error and switching signal variation. When the current error reaches the determined upper limit and lower limit, a signal is sent to the switching elements in the direction that will decrease or increase the current. Figure 6 shows the hysteresis current control technique algorithm. Here, the amplitude of the current to be drawn from the grid is obtained by passing the DC bus voltage error through the PI controller. DC bus voltage reference value is set to $400 \mathrm{~V}$ in the study. The controller generates switching signals of the rectifier to produce grid current that provides DC bus voltage regulation to $400 \mathrm{~V}$. The measured grid voltage is passed through the PLL, the grid angle is determined, and the synchronous current reference with the grid is obtained. The current error is obtained by subtracting the grid current from the reference current, and switching is done depending on this error value. Since there is no carrier signal in this control technique, the switching frequency varies. When the current error reaches up to the upper limit, it means that the current reaches the lower limit, and for the current to increase, the $S_{2}$ and $S_{3}$ switches are given an ON signal, while the $S_{1}$ and $S_{4}$ switches are given an OFF signal. Thus, the current flows within the desired bandwidth [19].

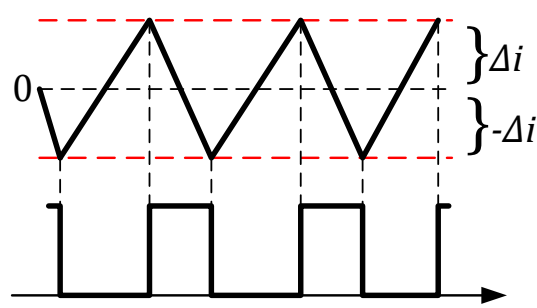

Figure 5. Current error and switching signal in HCC.

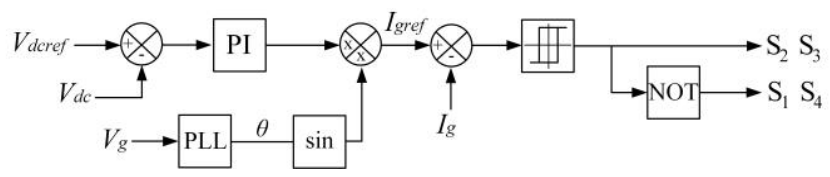


Figure 6. HCC control algorithm.

The waveforms that show the performance of the system in steady state are seen in Figure 7 . The parameters of PI controller are $\mathrm{k}_{\mathrm{p}}=0.2$ and $\mathrm{k}_{\mathrm{i}}=1.5$. As seen in Figure $7 \mathrm{a}$, the system has a $2.5 \mathrm{~kW}$ DC load. The controlled rectifier regulates the DC bus voltage to $400 \mathrm{~V}$, as shown in Figure $7 \mathrm{~b}$. In order to ensure this regulation, $11.4 \mathrm{~A}_{\mathrm{rms}}$ current is drawn from the grid as seen in Figure 7c. The grid current total harmonic distortion $\left(T H D_{I}\right)$ value is measured $3.69 \%$ at $2.5 \mathrm{~kW}$ nominal power. The harmonic content and waveform is given in Figure 8. As seen in Figure $7 d$, switching frequency varies in a period. The reason that the switching frequency variation is the voltage difference between the grid voltage and DC bus voltage. The difference voltage drops on the inductor, and it changes the slope of the grid current, and it causes frequency variation. As the difference has the highest value around zero voltage crossing points of grid voltage, it gets maximum value. The average switching frequency is $34.6 \mathrm{kHz}$.

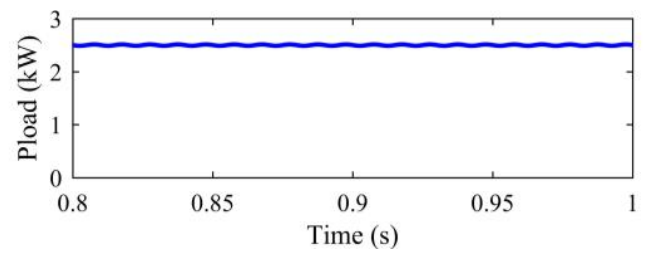

a) Load power

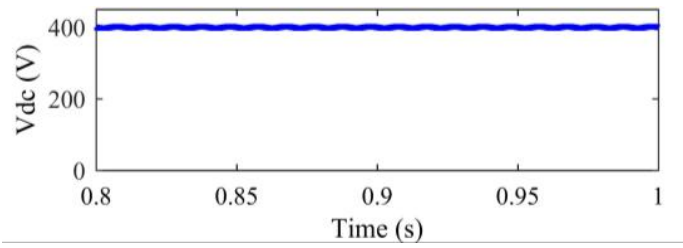

b) DC bus voltage

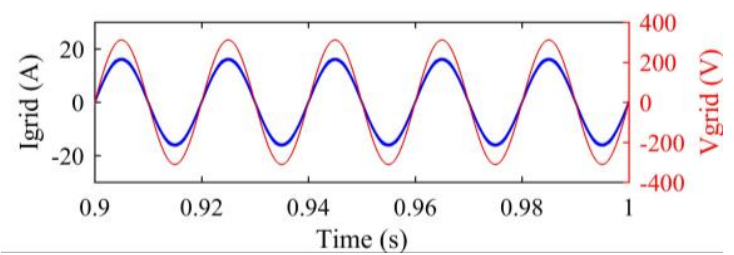

c) Grid current and voltage

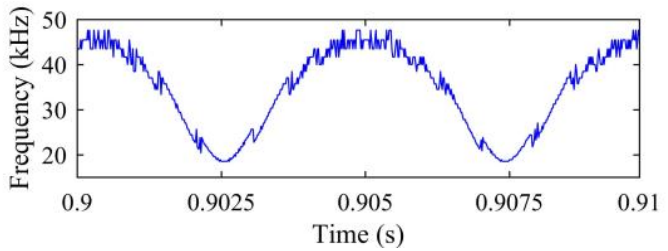

d) Switching frequency variation in a period

Figure 7. Steady-state performance of the system.

Switching frequency of HCC changes depending on the hysteresis band value. Lower band value causes higher switching frequency but provides lower $T H D_{I}$ as seen in Table 2. As switching frequency is selected $35 \mathrm{kHz}$ in SPWM and VOC techniques, hysteresis band value is set to 0.6 A because average switching frequency is 34.6 $\mathrm{kHz}$ that is near the $35 \mathrm{kHz}$ in the study.

Table 2. Switching frequency depending on the hysteresis band value

\begin{tabular}{ccc}
\hline $\begin{array}{c}\text { Hysteresis } \\
\text { band value } \\
(\Delta i)\end{array}$ & $\begin{array}{c}\text { Average } \\
\text { switching } \\
\text { frequency }\left(f_{s w}\right)\end{array}$ & $T H D_{I}$ \\
\hline $0.6 \mathrm{~A}$ & $34.6 \mathrm{kHz}$ & $3.69 \%$ \\
$0.5 \mathrm{~A}$ & $40 \mathrm{kHz}$ & $3.2 \%$ \\
\hline & $6.25 \mathrm{~A}$ & $1.92 \%$ \\
\hline
\end{tabular}

Figure 8. Harmonic measurement for $\Delta \mathrm{i}=0.6 \mathrm{~A}$

The transient response of the controller is also important to evaluate the system performance. For this reason, the load power of the system is changed in the simulation time interval. The DC bus regulation and grid current performance of the controller are examined in Figure 9. The load power shown in Figure 9a decreases from $2.5 \mathrm{~kW}$ to $2 \mathrm{~kW}$ at 1.2 seconds, and the power increases to $2.5 \mathrm{~kW}$ at 2 seconds. As seen in Figure 9b, the DC bus voltage changes depending on the load power change. The sudden decrease in the load causes increasing in the DC bus voltage. In this case, as seen in Figure 9c, the grid current is decreased by the controller to regulate the DC bus voltage. The opposite situation realized when the load power increases. The controller changes the grid current depending on the DC bus voltage. As can be seen from the figures, the controller provides DC bus voltage regulation by drawing sinusoidal and synchronized current with the grid voltage in steady-state and transient-state.

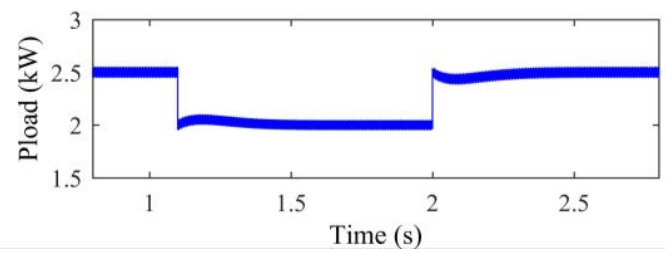

a) Load power 


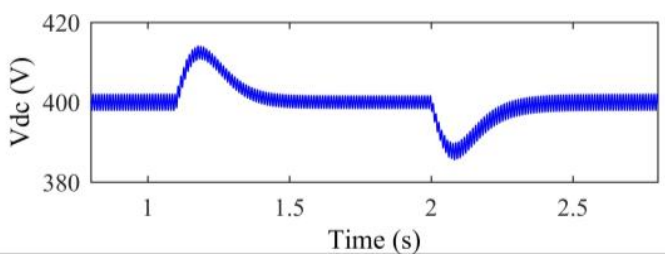

b) DC bus voltage

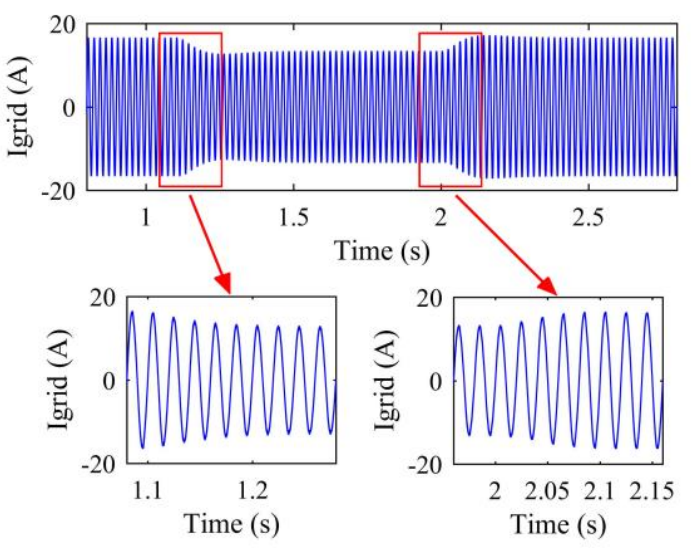

c) Grid current

Figure 9. Transient response of the system.

\subsection{Sinusoidal PWM}

In the sinusoidal PWM technique, unlike the HCC, switching signals are obtained by comparing a sinusoidal voltage with a triangle wave. The control algorithm is given in Figure 10. The reference current is generated by using the grid angle and reference grid current peak value that is obtained from the DC bus voltage error. The reference signal is generated by passing the current error through the proportional resonant (PR) controller. PWM signals are generated by comparing this signal with a triangle wave signal. This signal has $35 \mathrm{kHz}$ frequency that determines the circuit operating frequency. Since a sinusoidal signal is used in this control method, PR controller is used instead of PI controller [20]. The load power, DC bus voltage and grid current waveforms are seen in Figure 11. As seen in the figures, controller regulates the DC bus voltage by drawing a sinusoidal and synchronized grid current. The total harmonic distortion of the grid current at 2.5 $\mathrm{kW}$ is $\mathrm{THD}_{\mathrm{I}}=1.12 \%$ as seen in Figure 12 .



Figure 10. SPWM control algorithm.

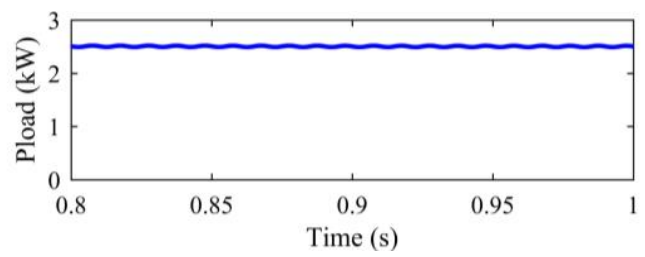

a) Load power

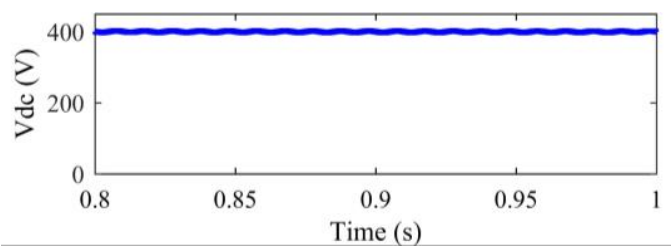

b) DC bus voltage

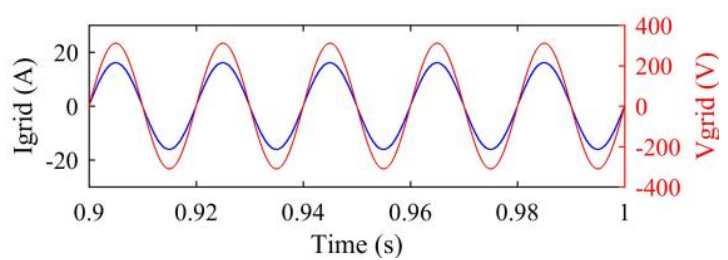

c) Grid current and voltage

Figure 11. Steady-state performance of the system

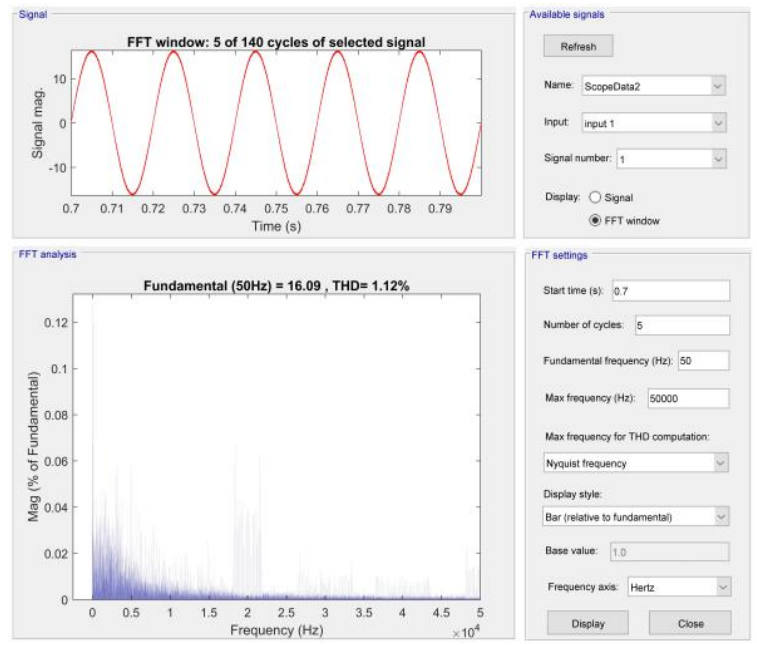

Figure 12. Harmonic measurement of the grid current As in the HCC control technique, load is changed to examine the transient performance of the control. As seen in Figure 13a, the load with a power of $2.5 \mathrm{~kW}$ decreased to $2 \mathrm{~kW}$ at 1.1 seconds and then increased to $2.5 \mathrm{~kW}$ again at the 2 . seconds. As a result of this, as seen in Figure 13b, the DC bus voltage moves away from the reference value, and as seen in Figure 13c, the DC bus voltage regulation is achieved by adjusting the grid current. PI controller parameters are $\mathrm{k}_{\mathrm{p}}=0.2$ and $\mathrm{k}_{\mathrm{i}}=1.5$, whereas $\mathrm{k}_{\mathrm{p}}=0.1$ and $\mathrm{ki}=1$ in PR controller. As in the HCC technique, in this control, a transition from transient to stable is achieved.

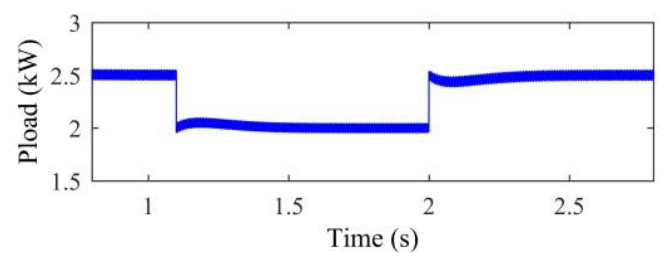

a) Load power 


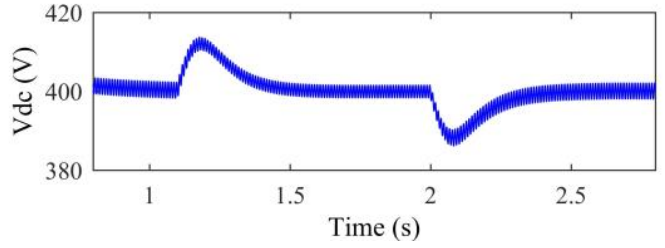

b) DC bus voltage

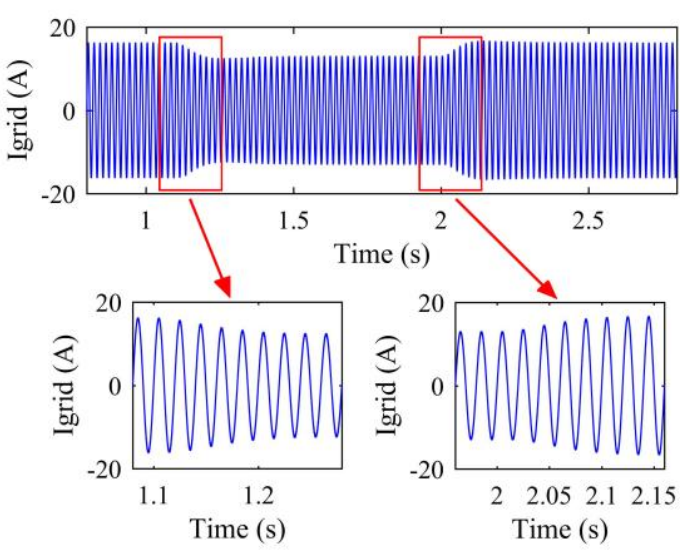

c) Grid current

Figure 13. Transient performance of the system.

\subsection{Voltage-Oriented Control}

Unlike other control techniques, voltage-oriented control technique is carried out in $d-q$ coordinate system [21]. As seen in Figure 14, firstly, the grid current is transformed to the $\alpha-\beta$ coordinate system. The $\beta$ component lags behind the alpha component by 90 degrees. The $\alpha$ component is the same as the grid current. This coordinate system is converted to the $d-q$ coordinate system, and thus the DC components of the grid current in the $d-q$ coordinate system are obtained. Thus, error regulation can be performed with the PI controller. Since the grid current is desired to be synchronized with the grid voltage, the reference value of the q-component of the current is set to zero. The reference value of the $d$-component comes from the DC bus voltage regulation. This value refers to the peak value of the grid current. With the help of PI controllers, errors in $d-q$ components are regulated, and reference $d-q$ voltages are produced. These voltages that are transformed into $\alpha-\beta$ coordinate system using the grid angle and switching signals are obtained by comparing the $\alpha$-component with the triangle signal. The performance of the system with this control technique is shown in Figure 15. Depending on the output power seen in Figure 15a, DC bus voltage regulation is achieved at $2.5 \mathrm{~kW}$ output power by the rectifier as seen in Figure 15b. It is provided by the grid current that is seen in Figure 15c. The total harmonic distortion value of the grid current is measured $1.82 \%$ that meets the harmonic limits defined in standards as seen in Figure 16. The PI parameters for $\mathrm{V}_{\text {dref }}$ and $\mathrm{V}_{\mathrm{qref}}$ are $\mathrm{k}_{\mathrm{p}}=0.015$ $\mathrm{k}_{\mathrm{i}}=0.15$, whereas $\mathrm{k}_{\mathrm{p}}=0.2$ and $\mathrm{k}_{\mathrm{i}}=1.5$ for DC bus voltage PI controller.
The transient performance of the system is examined under the same conditions as the other techniques. As seen in Figure 17, the control technique has good transient performance such as the other techniques.

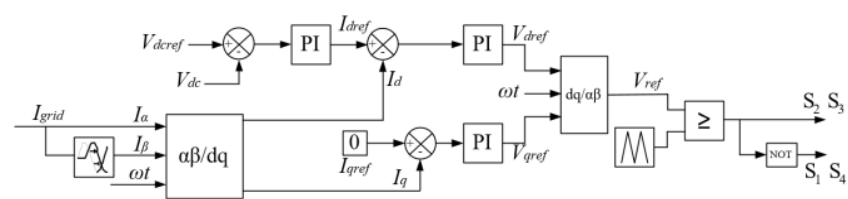

Figure 14. Voltage-oriented control algorithm

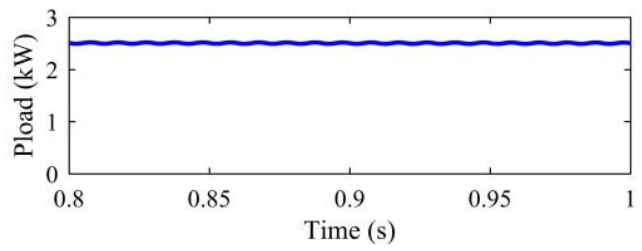

a) Load power

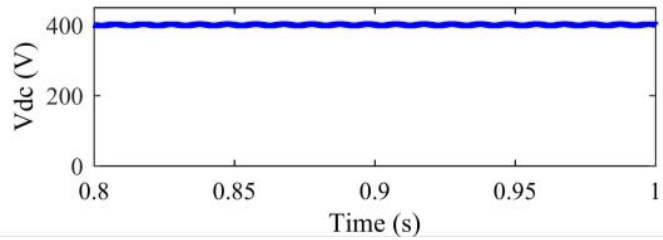

b) DC bus voltage

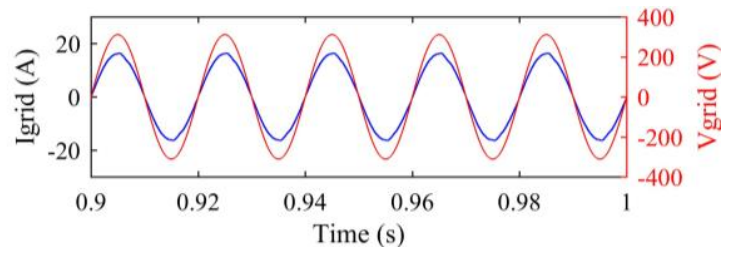

c) Grid current and voltage

Figure 15. Steady-state performance of the system

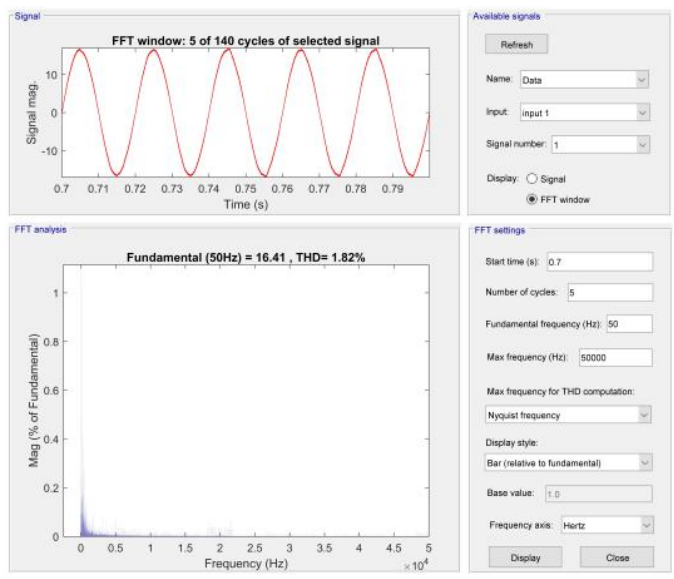

Figure 16. Harmonic measurement of the grid current 


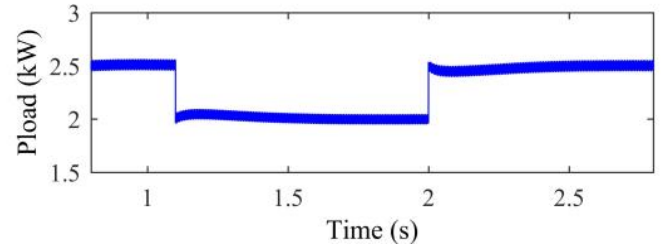

a) Load power

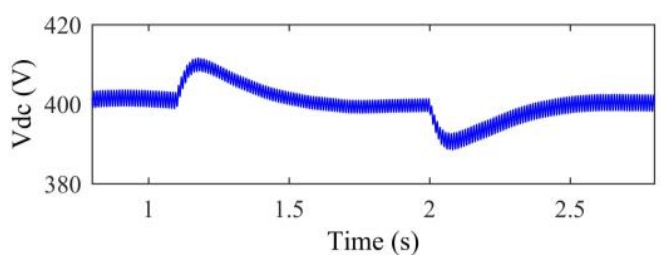

b) DC bus voltage

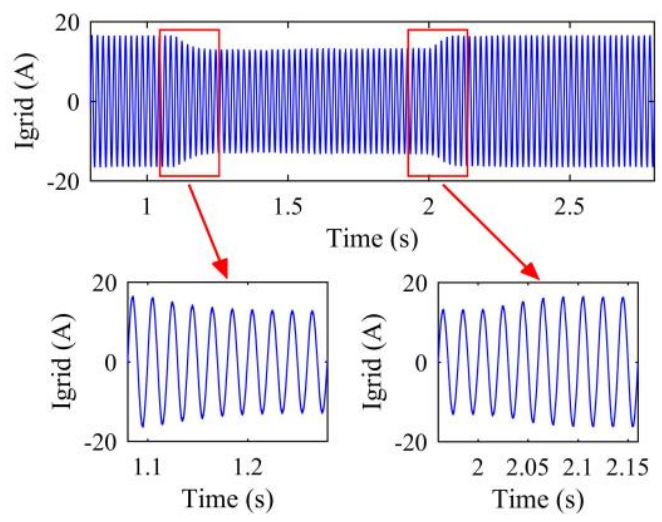

c) Grid current

Figure 17. Transient performance of the system.

\section{Discussion}

Three different control techniques, named hysteresis current control, sinusoidal PWM and voltage-oriented control, are applied to single-phase PWM rectifier. Table 3 shows the results of performance criteria of control techniques. As seen in the table, the switching frequency of HCC is different from other techniques because of variable switching frequency property of HCC. It depends on hysteresis band value. The switching frequency of HCC given in the table is average value $(34.6 \mathrm{kHz})$ that occurs with $0.6 \mathrm{~A}$ hysteresis band value. The frequency varies between $18.52 \mathrm{kHz}$ and $47.6 \mathrm{kHz}$. Although the controller algorithm is simple, the drawback of HCC is variable switching frequency and higher $T H D_{I}$ value. As seen in the table, the highest $T H D_{I}$ value is obtained in HCC technique. The other control techniques have lower $T H D_{I}$ value than the HCC. SPWM technique is applied with sinusoidal signals so PR regulator is used in the controller, whereas DC quantities are used in VOC technique. Because of the DC quantities, PI regulator is used in VOC technique. The sinusoidal signals are transformed to DC signals therefore higher computing power is required.

Table 3. Performance comparison of control techniques

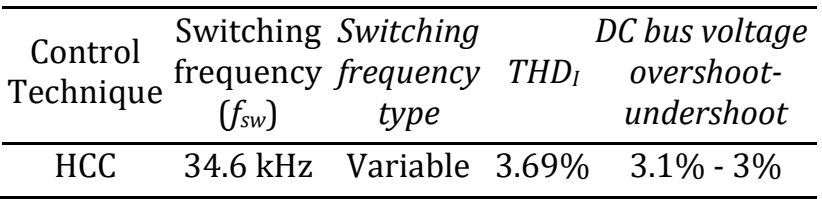

\begin{tabular}{ccccc}
\hline SPWM & $35 \mathrm{kHz}$ & Fixed & $1.12 \%$ & $3.1 \%-3 \%$ \\
VOC & $35 \mathrm{kHz}$ & Fixed & $1.82 \%$ & $2.2 \%-2.3 \%$ \\
\hline
\end{tabular}

\section{Conclusion}

In this study, the performance of single-phase PWM rectifier that is connected to a single-phase grid for three different control techniques is investigated. $400 \mathrm{~V}$ DC bus voltage is generated at the output of the rectifier with the power of $2.5 \mathrm{~kW}$. Hysteresis current control technique, sinusoidal pulse width modulation technique and voltage-oriented control technique are used in the converter control. The system performance is investigated for steady-state and transient-state. In both state, all techniques perform inadequate performance in terms of harmonic content and power factor. The generated grid current is synchronized with grid voltage for three techniques. Total harmonic distortion value of the grid current is $3.69 \%, 1.12 \%$ and $1.82 \%$ for HCC, SPWM and VOC techniques, respectively. The results obtained in all three control techniques show that three techniques can be used in such a system. HCC technique has more simple control algorithm than the others but because of variable switching frequency and lower THD performance, the other control techniques are more efficient for the rectifier.

\section{References}

[1] Pichan, M., Abrishamifar, A., Ahmad, A.A. and Fazeli, M., "Simple and Efficient Design and Control of the Single Phase PWM Rectifier for UPS Applications", 8th Power Electronics, Drive Systems \& Technologies Conference, 2017, 383-388.

[2] Mansour, M., Mansouri, M.N., Bendoukha, S. and Mimouni, M.F., "A grid-connected variable-speed wind generator driving a fuzzy-controlled PMSG and associated to a fly Wheel energy storage system", Electric Power Systems Research, Vol. 180, 1-13, 2020.

[3] Pan, L. and Zhang, C., "Model Predictive Control of a Single-Phase PWM Rectifier for Electric Vehicle Charger", Energy Procedia, Vol. 105, 4027-4033, 2017.

[4] Tawfeeq, O.T., Ibrahim, A.Y. and Alabbawi, A.A.M., "Study of a Five-Level PWM Rectifier Fed DC Motor Drive", 7th International Conference on Electrical and Electronics Engineering, 2020, 126-129.

[5] Afghoul, H., Krim, F., Chikouche, D. and Beddar, A., "Design and real time implementation of fuzzy switched controller for single phase active power filter", ISA Transactions, Vol. 58, 614-621, 2015.

[6] Ilonciak, J., Struharnansky, L. and Kuchta, J., "Modular concept of auxiliary converters for diesel electric locomotives", Procedia Engineering, Vol. 192, 359-364, 2017.

[7] Mengi, O., Yanmaz, K. and Altaş, I.H., "STATCOM application with FLC and voltage control on the load in the hybrid model of fuel cell/solar panels 
system", Mugla Journal of Science and Technology, Vol. 3 No. 1, 45-50, 2017.

[8] Kolar, J.W. and Friedli, T., "The Essence of ThreePhase PFC Rectifier Systems-Part I", IEEE Transactions on Power Electronics, Vol. 28, No. 1, 176-198, 2013.

[9] Mohan, N. Undeland, T. and Robbins, W., Power Electronics-Converters, Application, and Design. 2nd Edition, John Wiley \& Sons, Inc., Canada, 1995.

[10] McCarty, M., Taufik, T., Pratama, A. and Anwari, M., "Harmonic analysis of input current of single- phase controlled bridge rectifier", IEEE Symposium on Industrial Electronics \& Applications, 2009, 520-524.

[11] Frisfelds, K. and Krievs, O., "Design of a three-phase bidirectional PWM rectifier with simple control algorithm", Latvian Journal of Physics and Technical Sciences, Vol. 16, No. 3, 3-12, 2019.

[12] Cho, Y., Han, Y., Madhusoodhanan, S., Ha, J.I. and Bhattacharya, S., "Synchronous Frame Full-Order Observer Design for Three-Phase Buck-Type PWM Rectifier", 42nd Annual Conference of the IEEE Industrial Electronics Society, 2016, 3618-3622.

[13] Sawachan, H., Liutanakul, P. and Wiwatcharagoses, N., "A Simple Dead-Time Compensation Technique for Single-Phase Full-Bridge PWM Rectifier", 5th International Electrical Engineering Congress, 2017, 1-4.

[14] Gomes, C. C., Cupertino, A. F. and Pereira H. A., "Damping techniques for grid-connected voltage source converters based on LCL filter: An overview", Renewable and Sustainable Energy Reviews, Vol. 81, No. 1, 116-135, 2018.

[15] Pan, D., Ruan, X., Bao, C., Li, W. and Wang, X., "Capacitor-Current-Feedback Active Damping With Reduced Computation Delay for Improving Robustness of LCL-Type Grid-Connected Inverter", IEEE Transactions on Power Electronics, Vol. 29, No. 7, 3414-3427, 2014

[16] He, H., Li, Z., Si, T. and Sun, L., "Research on Digital Phase Locked Method in PWM Rectifier", IEEE 8th Joint International Technology and Artificial Intelligence Conference, 2019, 1866-1870.

[17] Zhu, P., Wei, Y., Zheng, Z., Wang, X. and Ma, F., "Fractional Modeling and Simulation for SinglePhase PWM Rectifier", The Journal of Engineering, Vo. 2019, No. 16, 1675-1688, 2019.

[18] Komurcugil, H., "Double-band hysteresis currentcontrolled single-phase shunt active filter for switching frequency mitigation", Electrical Power and Energy System, Vol. 69, 131-140, 2015.

[19] Isen, E., "Modelling and Simulation of Hysteresis Current Controlled Single-Phase Grid-Connected Inverter", International Conference on Electrical and Power Engineering, 2015, 322-326.

[20] Karafil, H. and Ozbay, H., "Power Control of Single Phase Active Rectifier", Balkan Journal of Electrical \& Computer Engineering, Vol. 7, No. 3, 332-336, 2019.
[21] Isen, E. and Bakan, F., "Highly efficient three-phase grid-connected parallel inverter system", Journal of Modern Power Systems and Clean Energy, Vol. 6, 1079-1089, 2018. 